\title{
Assessment of heavy metal pollution in soil and bottom sediment of Upper Egypt: comparison study
}

\author{
Esmat Ahmed Abou El-Anwar(D)
}

\begin{abstract}
Background: Aswan and Luxor Governorates are characterized by multifaceted activities such as cement, chemicals, fertilizers, detergents, nitrogen fertilizer factory at Aswan, the sugar and diary factory at Kom Ombo, and several other factories such as the sugar, pulp, paper, ferrosilicon, and phosphate factories at Edfu, urbanization and agriculture. In addition, there is a main sewage station which is used for irrigation of many crops. Assessing the pollution of soil and sediment with some heavy metals in these areas is the main aim of the current work.
\end{abstract}

Results: The average heavy metals content in the studied cultivated soils and Nile sediments are above the acceptable levels. Generally, Nile sediments and cultivated soils at Aswan and Luxor were unpolluted to moderately polluted with heavy metals. Pollution indices indicated that the studied Nile sediments were at considerably ecological risk from $\mathrm{Cd}$ $(E r=138.89)$ and $\mathrm{Zn}(E r=140.52)$. In contrast, the cultivated soil was at very high ecological risk from $\mathrm{Cd}(\mathrm{Er}=295.24)$.

Conclusions: The current research revealed that the soil and sediments in the Upper Egypt are less polluted than Lower Egypt. Thus, the concentrations of toxic elements are increased from south to north direction in Egypt along the Nile River. The sources of the toxic metals may possibly be natural or anthropogenic in the studied area. The anthropogenic source is resulting from paper, pulp, ferrosilicon factories, and phosphate mining at Edfu. In addition, there are some polluting industries such as sand quarry, shale mining, and the nitrogen fertilizer factory at Aswan. On the other hand, the natural sources of toxic waste are the drains during the seasonal flash floods.

Keywords: Heavy metals, Pollution indices, Upper Egypt, Contamination, Cultivated soil

\section{Background}

Heavy metals are present in the earth's environment. They are generated from anthropogenic and/or natural activities. Heavy metal pollution of soils and the environment is the result from industrialization, urbanization, and intensified irrigation water (Ali et al. 2019). Heavy metals pollution led to the poor soil health (Abdu, et al., 2017 and Bakshi, et al., 2018), surface and groundwater (Mohankumar, et al., 2016) and food contamination (Tchounwou, et al., 2012), which is a hazard to human health (Jovanović, et al., 2015; Oliver and Gregory, 2015; Sarwar, et al., 2017 and Yang, et al., 2017; Ali and Khan 2019). Therefore, the information of the heavy metal contamination of soils is needed to decide

Correspondence: abouelanwar2004@yahoo.com

Geological Sciences Department, National Research Center, Cairo, Egypt the combined efforts of governments and scientific communities.

Thus, the aim of this investigation is to defy the soil characterization and environmental assessment of the cultivated soils and Nile sediments of Upper Egypt, (Aswan Luxor District), located at latitude $23^{\circ} 5840$ to $25^{\circ} 43$ 9 $\mathrm{N}$ and long. $32^{\circ} 50$ to $33^{\circ} \mathrm{S}$ (Fig. 1). The study area characterized by complex activities; including big industries such as cement, chemical, fertilizers, detergents, nitrogen fertilizer factory at Aswan, the sugar and diary factory at Kom Ombo, and several other factories such as the sugar, pulp, paper, ferrosilicon, and phosphate factories at Edfu, urbanization and agriculture. In addition, there is a main sewage station which is used for irrigation of many crops. These studies can provide information about the distribution, speciation, and bioavailability of the heavy metals in the studied area, and the environmental assessment can indicate the sources of 


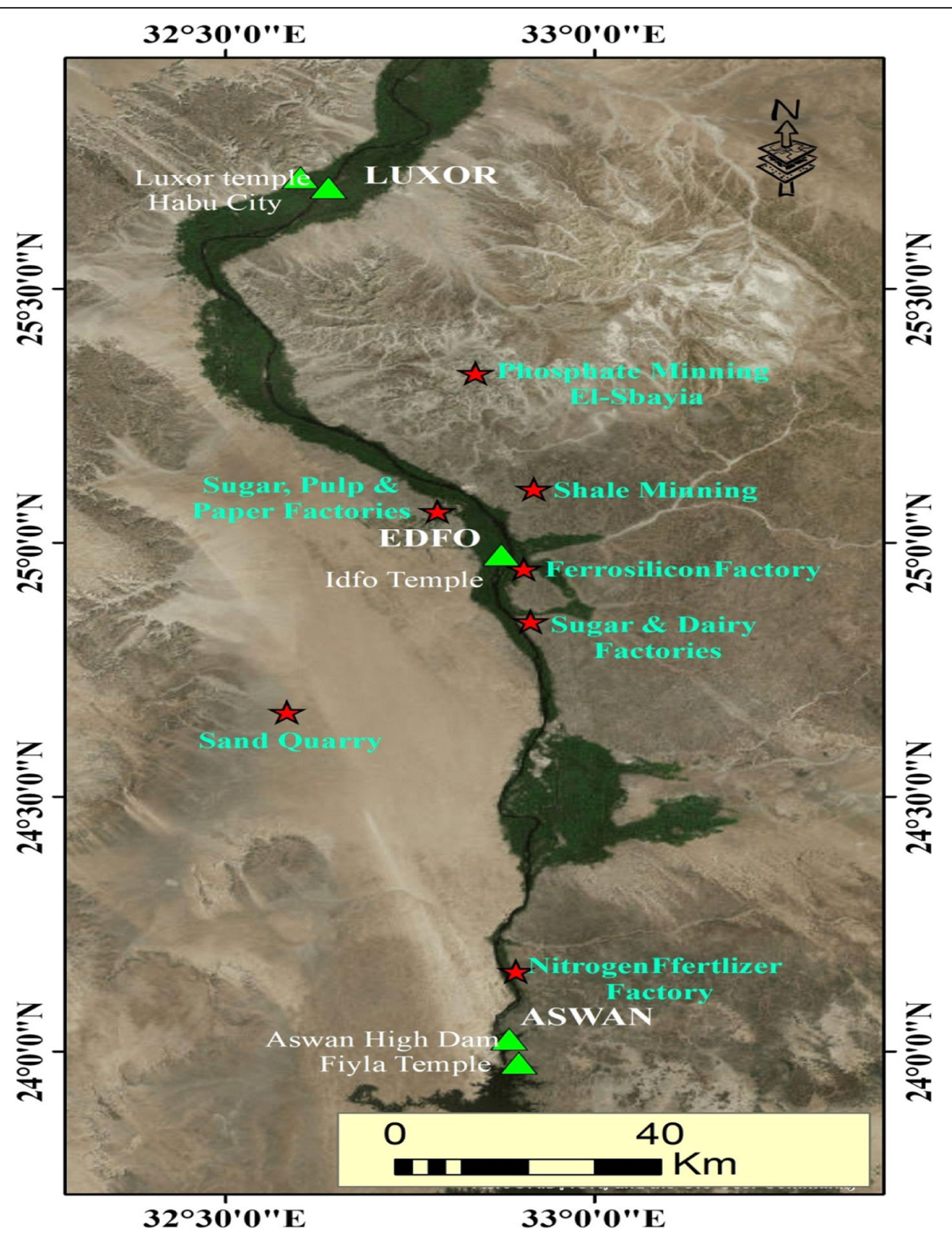

Fig. 1 Location map of the studied area

contamination and health hazards and finally, tries to offer some recommendations which facilitate to decrease its effect. In addition, try comparing the contemplation of pollution between Upper Egypt (Aswan and Luxor District) and others in Upper Egypt, as well as Rosetta Branch as Lower Egypt.

\section{Materials and methods}

Bottom sediment samples were collected from the main Nile path between Luxor and Aswan district. Samples were essentially taken from the upper $30 \mathrm{~cm}$ of the Nile sediments at water depth of about 0.5 meter. The cultivated soil samples were collected to represent the eastern and western flank of the Nile from 7 stations (Fig. 1). The samples were air-dried, ground, passed through a $2 \mathrm{~mm}$ sieve, and then oven-dried at $110^{\circ} \mathrm{C}$ for $3 \mathrm{~h}$. Each sample was ground to pass through a 63-mesh sieve and homogenized for analysis. For the determination of total metal concentration, exactly $1 \mathrm{~g}$ of powdered soil sample was digested with aqua regia $\left(\mathrm{HNO}_{3}\right.$ : $\mathrm{HCl}=1: 3$ ). The elements were determined in the extract by the atomic absorption. Single and integrated pollution indices were applied to evaluate the anthropogenic and natural impacts on contents of heavy metals in sediments and soils along Aswan - Luxor District. 


\section{Results}

Heavy metal concentrations of the cultivated soil (Hapo city, Edfo, High Dam, and Fiyla), and Nile sediments (Aswan - Luxor District), at Upper Egypt, are given in Table 1 and Fig. 2. The average heavy metal concentrations in the studied cultivated soil are 63876 ppm Fe; 3.2 ppm As; 12.04 ppm Pb; 142.5 ppm Cr; 0.57 ppm Cd; 31 ppm Co; 244 ppm Zn; 19 ppm Cu; 57 ppm Ni; and 2367 ppm Mn. In contrast, the average heavy metal contents in the study of Nile sediments are $56060 \mathrm{ppm} \mathrm{Fe} ; 0.24$ ppm As; 41 ppm Pb; 110 ppm Cr; 0.78 ppm Cd; 11 ppm Co; 114 ppm Zn; 10 ppm Cu; 16 ppm Ni; 1288 ppm Mn; $0.52 \mathrm{ppm} \mathrm{U}$; and $3.82 \mathrm{ppm} \mathrm{Th}$.

\section{Discussions}

Pollution indices are controlling implement for environmental quality evaluation. Generally, the pollution indices for heavy metals in soils and sediments are categorize as single and integrated pollution index (Qingjie, et al., 2008 and Hafizur Rahman, et al., 2012). The current studies, four single indices; index of geoaccumulation $\left(\mathrm{I}_{\text {geo }}\right)$, contamination factor $(\mathrm{CF})$, enrichment factor (EF), and ecological risk factor (Er), as well as, three integrated indices; degree of contamination (DC), pollution load index (PLI), and pollution ecological risk index (PRI), were used.

\section{Index of geoaccumulation $\left(\mathrm{I}_{\text {geo }}\right)$}

The index of geoaccumulation ( $\mathrm{I}_{\text {geo }}$ ) was firstly defined with Muller (1979) to determine and identify metal contamination of soil and sediments (Loska, et al., 2004; Praveena, et al., 2007 and 2008; Chakravarty and Patgiri, 2009 and Gao and Chen, 2012).

$$
\mathrm{I}_{\text {geo }}=\log _{2}(\mathrm{Cn} / 1.5 \mathrm{Bn})
$$

where: $\mathrm{Cn}$ is the measured concentration of metal in sediment and $\mathrm{Bn}$ is the geochemical background concentration of it. In this study, the concentrations of elements in the surface sediment of Lake Nasser (Goher, et al., 2014) and As and Co (Kabata-Pendias, and Mukherjee, 2007) were used as background values: $\mathrm{I}_{\text {geo }} \leq 0$ practically uncontaminated; $0<\mathrm{I}_{\text {geo }} \leq 1$ uncontaminated to moderately contaminated; $1<\mathrm{I}_{\text {geo }} \leq 2$ moderately contaminated; $2<$ $\mathrm{I}_{\text {geo }} \leq 3$ moderately to heavily contaminated; $3<\mathrm{I}_{\text {geo }} \leq 4$ heavily contaminated; $4<\mathrm{I}_{\text {geo }} \leq 5$ heavily to extremely contaminated; and $\mathrm{I}_{\text {geo }}>5$ extremely contaminated.

The index of geoaccumulation results (Table 2 and Fig. 3) reveals that the sediments and cultivated soils of the Aswan-Luxor area are unpolluted - moderately. But $\mathrm{Zn}$ is classified as moderately polluted in cultivated soils (Muller, 1979).

\section{Contamination factor (CF)}

It is used to illustrate the contamination of a given toxic element and assess the soil contamination (Hakanson 1980 and Liu, et al., 2005).

$$
\mathrm{CF}=\mathrm{C}_{\mathrm{s}} / \mathrm{C}_{\mathrm{b}}
$$

where $C_{s}$ is the concentration of metal in the study samples and $C_{b}$ is baseline concentration as in index of geoaccumulation. Hakanson (1980) classified the concentration factor as the following; $\mathrm{CF}<1$ low; $1<\mathrm{CF}<$ 3 moderate; $3<\mathrm{CF}<6$ considerable, and $\mathrm{CF}>6$ as high contamination.

\begin{tabular}{|c|c|c|c|c|c|c|c|c|c|c|c|c|}
\hline Sample No & Location & type & $\mathrm{Fe}$ & As & $\mathrm{Pb}$ & $\mathrm{Cr}$ & $\mathrm{Cd}$ & Co & $\mathrm{Zn}$ & $\mathrm{Cu}$ & $\mathrm{Ni}$ & $\mathrm{Mn}$ \\
\hline 1 & Luxor & Nile Sediments & 22592 & 0.2 & 39.8 & 193.9 & 0.5 & 5.5 & 128.6 & 6.6 & 13.7 & 488.9 \\
\hline 2 & & & 29446 & 0.21 & 40.5 & 201 & 0.5 & 7.5 & 150 & 7.5 & 15.2 & 497 \\
\hline 3 & & & 23781 & 0.31 & 45.2 & 210 & 0.4 & 9.2 & 145 & 6.9 & 14.3 & 510.1 \\
\hline 4 & Aswan & & 88478 & 0.01 & 42.7 & 15.6 & 0.8 & 15.4 & 72.2 & 8.7 & 15.9 & 2094 \\
\hline 5 & & & 80435 & 0.02 & 60.4 & 13.2 & 1.1 & 12.5 & 80.5 & 22 & 14.8 & 2140 \\
\hline 6 & & & 91625 & 1.3 & 17.7 & 25.7 & 1.4 & 15.6 & 105.3 & 10.7 & 19.5 & 1995 \\
\hline Average & & & 56059.5 & 0.34 & 41.05 & 109.9 & 0.78 & 10.95 & 113.6 & 10.40 & 15.57 & 1287.5 \\
\hline 7 & Habo City & Agricultural Soil & 81693 & 5.3 & 11.4 & 150.1 & 0.7 & 26.8 & 135.2 & 20.8 & 83.1 & 1129 \\
\hline 8 & & & 73839 & 5.6 & 13.4 & 160 & 0.8 & 30 & 140 & 25 & 90.5 & 1340 \\
\hline 9 & & & 87089 & 6.2 & 15.6 & 145 & 0.9 & 32 & 145 & 23 & 94.8 & 1546 \\
\hline 10 & Edfo & & 85960 & 5.2 & 9.5 & 121.4 & 0.5 & 34.8 & 113.1 & 17.6 & 71.2 & 71.2 \\
\hline 11 & High Dam & & 41057 & 0.02 & 9.1 & 131.1 & 0.3 & 28.6 & 373 & 16.3 & 14.9 & 1044.9 \\
\hline 12 & & & 34622 & 0.03 & 10.2 & 140 & 0.4 & 30.5 & 390 & 17.8 & 20.5 & 11054 \\
\hline 13 & Fiyla & & 42875 & 0.04 & 15.1 & 150 & 0.4 & 35.2 & 410 & 12.5 & 23.3 & 380.5 \\
\hline Average & & & 63876.4 & 3.20 & 12.04 & 142.51 & 0.57 & 31.13 & 243.8 & 19.0 & 56.9 & 2366.5 \\
\hline
\end{tabular}

Table 1 Concentration of the heavy metals (ppm) for the studied sample 


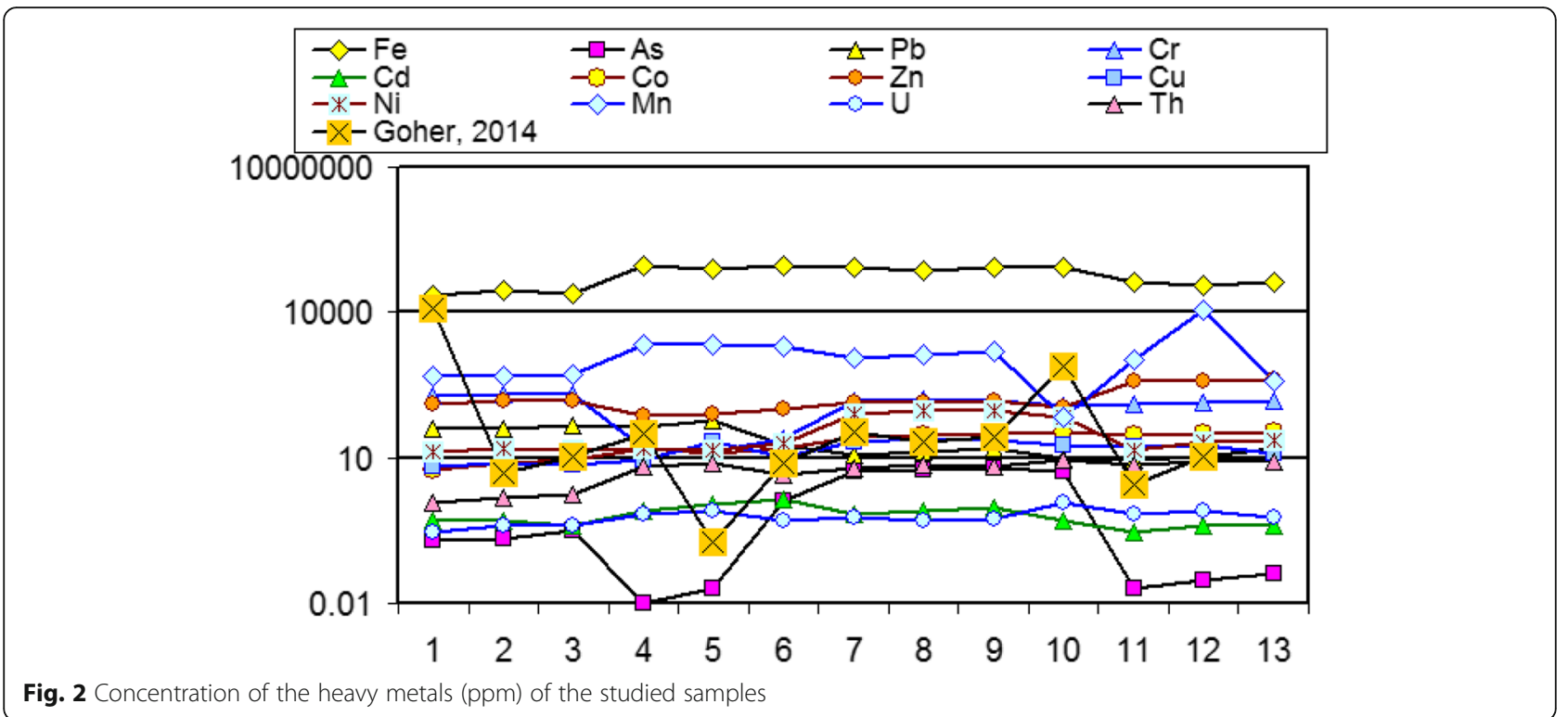

The calculated contamination factor (Table 3 and Fig. 4) indicated that all the sediments samples are low contaminated with $\mathrm{As}, \mathrm{Cu}$, and $\mathrm{Ni}$. Fe and $\mathrm{Co}$ represented as moderate contamination, and considerably contamination with $\mathrm{Pb}, \mathrm{Cr}, \mathrm{Cd}$, and $\mathrm{Zn}$. In contrast, the cultivated samples are low contaminated with $\mathrm{As}$ and $\mathrm{Cu}$. $\mathrm{Fe}, \mathrm{Pb}$, and $\mathrm{Ni}$ show moderate contamination, and $\mathrm{Cr}, \mathrm{Cd}$, and $\mathrm{Co}$ are considerably contaminated and high polluted with $\mathrm{Zn}$.

\section{Enrichment factor (EF)}

It is a factor applied to determine if the soils and sediments are enriched in trace elements compared with an uncontaminated reference material and distribution of the elements of anthropogenic origin (Simex and Helz, 1980). Also, it evaluates the degree of contamination in the environment (Franco-Uria, et al., 2009). Fe was chosen as a normalizing element (Loska, et al., 2003 and Seshan, et al., 2010).

EF values $<2$ indicate that the metal completely comes from the crust materials; whereas $\mathrm{EF}>2$ revealed the anthropogenic sources (Liaghati, et al., 2003). The EF values < 2 indicate depletion to minimal enrichment, 2-5 indicate moderate enrichment, 5-20 indicate significant enrichment, 20-40 indicate very high enrichment, and EF > 40 indicate extremely high enrichment. In this study, Fe is also used as

Table 2 Index of geoaccumulation $\left(\mathrm{I}_{\text {geo }}\right)$ values for the studied samples

\begin{tabular}{|c|c|c|c|c|c|c|c|c|c|c|c|}
\hline Sample No & Location & type & $\mathrm{Fe}$ & As & $\mathrm{Pb}$ & $\mathrm{Cr}$ & $\mathrm{Cd}$ & Co & $\mathrm{Zn}$ & $\mathrm{Cu}$ & $\mathrm{Ni}$ \\
\hline 1 & Luxor & Nile Sediments & 0.37 & 0.01 & 0.73 & 1.26 & 0.57 & 0.14 & 0.73 & 0.06 & 0.10 \\
\hline 2 & & & 0.48 & 0.01 & 0.74 & 1.31 & 0.57 & 0.19 & 0.85 & 0.07 & 0.11 \\
\hline 3 & & & 0.38 & 0.01 & 0.83 & 1.37 & 0.46 & 0.23 & 0.82 & 0.06 & 0.10 \\
\hline 4 & Aswan & & 1.43 & 0.00 & 0.79 & 0.10 & 0.92 & 0.39 & 0.41 & 0.08 & 0.11 \\
\hline 5 & & & 1.30 & 0.00 & 1.11 & 0.09 & 1.26 & 0.32 & 0.46 & 0.20 & 0.11 \\
\hline 6 & & & 1.41 & 0.05 & 0.33 & 0.17 & 1.60 & 0.40 & 0.60 & 0.10 & 0.14 \\
\hline Average & & & 0.90 & 0.01 & 0.76 & 0.72 & 0.90 & 0.28 & 0.65 & 0.10 & 0.11 \\
\hline 7 & Habo City & Agricultural Soil & 0.13 & 0.21 & 0.21 & 0.98 & 0.80 & 0.68 & 0.77 & 0.19 & 0.60 \\
\hline 8 & & & 1.19 & 0.22 & 0.25 & 1.04 & 0.92 & 0.76 & 0.79 & 0.23 & 0.65 \\
\hline 9 & & & 1.41 & 0.25 & 0.29 & 0.95 & 1.03 & 0.81 & 0.82 & 0.21 & 0.68 \\
\hline 10 & Edfo & & 1.39 & 0.21 & 0.17 & 0.79 & 0.57 & 0.88 & 0.64 & 0.16 & 0.51 \\
\hline 11 & High Dam & & 0.66 & 0.00 & 0.17 & 0.85 & 0.34 & 0.73 & 2.12 & 0.15 & 0.11 \\
\hline 12 & & & 0.56 & 0.00 & 0.19 & 0.91 & 0.46 & 0.80 & 2.21 & 0.16 & 0.15 \\
\hline 13 & Fiyla & & 0.69 & 0.00 & 0.28 & 0.98 & 0.46 & 0.89 & 2.33 & 0.12 & 0.17 \\
\hline Average & & & 0.86 & 0.13 & 0.22 & 0.93 & 0.65 & 0.79 & 1.38 & 0.17 & 0.41 \\
\hline
\end{tabular}




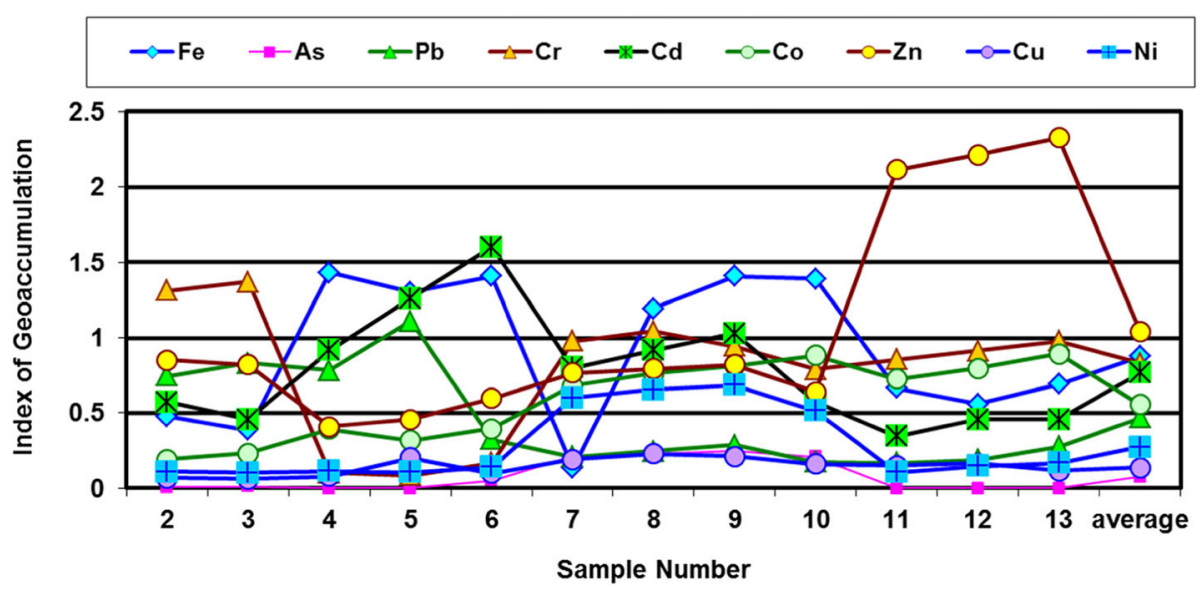

Fig. 3 Index of Geoaccumulation $\left(I_{\text {geo }}\right)$ of the heavy metals of the studied samples

tracer to differentiate natural from anthropogenic components.

Enrichment Factor $(\mathrm{EF})=(\mathrm{M} / \mathrm{Fe})$ sample $/(\mathrm{M} / \mathrm{Fe})$ backg

The enrichment factor of the study sediments (Table 4 and Fig. 5) revealed that they were ranged from low to high enrichment. EF of the all elements is low enrichment. $\mathrm{Zn}$ is relatively high enrichment for the cultivated soils.

\section{Ecological risk factor $(\mathrm{Er})$}

The degree of hazard contamination in sediments and soils is indicated by the ecological risk factor (Er), which is suggested by Hakanson (1980):

$$
\mathrm{Er}=\operatorname{Tr} \times \mathrm{CF}
$$

This factor depends on contamination factor (CF) and the toxic-response factor ( $\mathrm{Tr})$, which is calculated by 5, and 1 for $\mathrm{As}, \mathrm{Pb}, \mathrm{Cr}, \mathrm{Cd}, \mathrm{Co}, \mathrm{Cu}, \mathrm{Ni}$, and $\mathrm{Zn}$. $\mathrm{Er}<40$ indicated low potential ecological risk; $40 \leq \mathrm{Er}<80$ moderate probable ecological risk; $80 \leq \mathrm{Er}<160$ considerable possible ecological risk; $160 \leq \mathrm{Er}<320$ high potential ecological risk, and finally $\mathrm{Er} \geq 320$ represented a very high potential ecological risk.

The average value of the ecological risk factor (Er) of the studied Nile sediments(Table 5 and Fig. 6) indicated that the area was considerably ecological risk with $\mathrm{Zn}$ and $\mathrm{Cd}(\sim 139$ and 141, respectively), which is

Table 3 Contamination factor, degree of contamination, and pollution load index pollution of the heavy metals of the study samples

\begin{tabular}{|c|c|c|c|c|c|c|c|c|c|c|c|c|c|}
\hline Sample No & Location & type & $\mathrm{Fe}$ & As & $\mathrm{Pb}$ & $\mathrm{Cr}$ & $\mathrm{Cd}$ & Co & $\mathrm{Zn}$ & $\mathrm{Cu}$ & $\mathrm{Ni}$ & DC & PLI \\
\hline 1 & Luxor & Nile Sediments & 0.64 & 0.04 & 3.65 & 6.30 & 2.86 & 0.70 & 3.63 & 0.30 & 0.50 & 18.62 & 0.95 \\
\hline 2 & & & 0.84 & 0.04 & 3.71 & 6.53 & 2.86 & 0.95 & 4.24 & 0.34 & 0.55 & 20.07 & 1.08 \\
\hline 3 & & & 0.67 & 0.06 & 4.14 & 6.82 & 2.29 & 1.16 & 4.10 & 0.32 & 0.52 & 20.08 & 1.09 \\
\hline 4 & Aswan & & 2.51 & 0.02 & 3.91 & 0.51 & 4.57 & 1.95 & 2.04 & 0.40 & 0.58 & 16.49 & 0.91 \\
\hline 5 & & & 2.28 & 0.01 & 5.54 & 0.43 & 6.29 & 1.58 & 2.28 & 1.01 & 0.54 & 19.94 & 0.91 \\
\hline \multirow[t]{2}{*}{6} & & & 2.60 & 0.01 & 1.62 & 0.83 & 8.00 & 1.97 & 2.98 & 0.49 & 0.71 & 19.22 & 0.92 \\
\hline & & & 1.59 & 0.03 & 3.76 & 3.57 & 4.48 & 1.39 & 3.21 & 0.48 & 0.56 & 19.07 & 0.98 \\
\hline 7 & Habo City & Agricultural Soil & 2.32 & 1.10 & 1.04 & 4.87 & 4.00 & 3.39 & 3.82 & 0.96 & 3.02 & 24.52 & 2.32 \\
\hline 8 & & & 2.09 & 1.17 & 1.23 & 5.20 & 4.57 & 3.80 & 3.96 & 1.15 & 3.28 & 26.44 & 2.52 \\
\hline 9 & & & 2.47 & 1.29 & 1.43 & 4.71 & 5.14 & 4.05 & 4.10 & 1.06 & 3.44 & 27.69 & 2.66 \\
\hline 10 & Edfo & & 2.44 & 1.08 & 0.87 & 3.94 & 2.86 & 4.41 & 3.20 & 0.81 & 2.58 & 22.19 & 2.09 \\
\hline 11 & High Dam & & 1.16 & 0.00 & 0.83 & 4.26 & 1.71 & 3.62 & 10.54 & 0.75 & 0.54 & 23.43 & 0.85 \\
\hline 12 & & & 0.98 & 0.00 & 0.93 & 4.55 & 2.29 & 3.86 & 11.02 & 0.82 & 0.74 & 25.20 & 1.00 \\
\hline 13 & Fiyla & & 1.22 & 0.27 & 1.38 & 4.87 & 2.29 & 4.46 & 11.59 & 0.57 & 0.85 & 27.49 & 1.71 \\
\hline Average & & & 1.81 & 0.70 & 1.10 & 4.63 & 3.27 & 3.94 & 6.89 & 0.87 & 2.06 & 25.28 & 1.88 \\
\hline
\end{tabular}




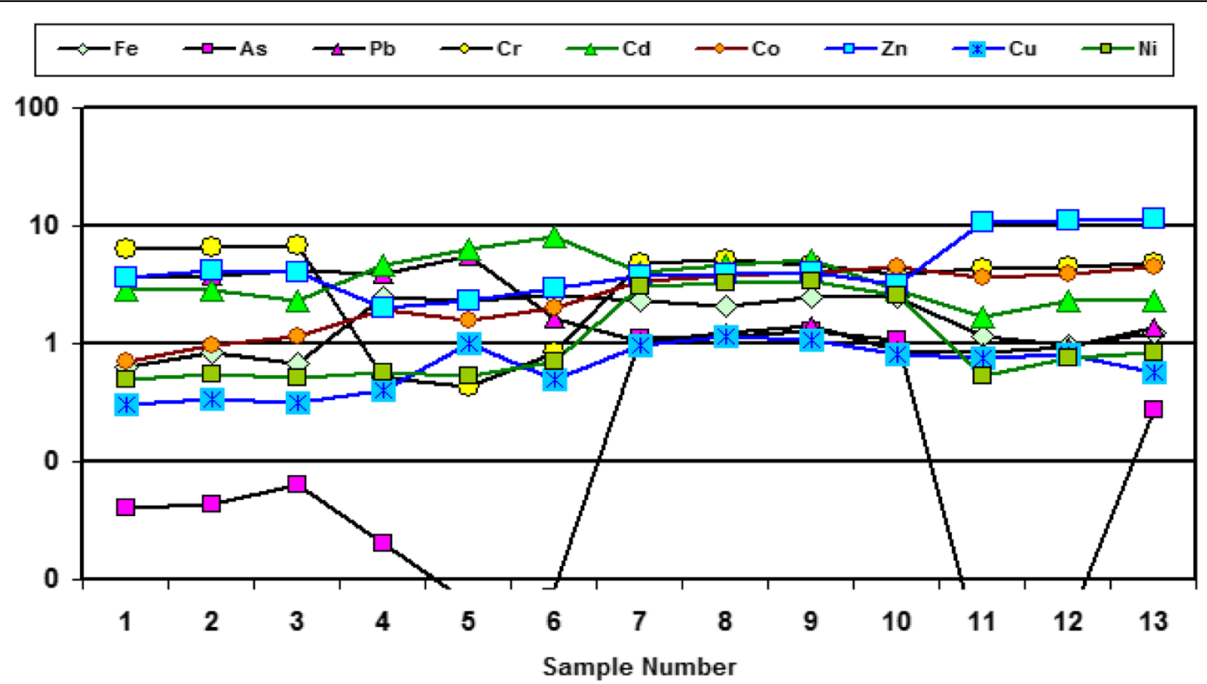

Fig. 4 Contamination factor of the heavy metals of the studied samples

compatible with the results of the index of geoaccumulation $\left(\mathrm{I}_{\text {geo }}\right)$. Er of the studied cultivated soils was a very high ecological risk with $\mathrm{Cd}(\sim 296)$. In addition, the recorded values of $\mathrm{Pb}, \mathrm{Cu}$, and $\mathrm{Ni}$ are represented as a low ecological risk.

\section{The integrated pollution indices}

The integrated pollution indices (DC, PLI, and PRI) are significant factors to identify the contamination resulting from the increased elements concentrations (Chon et al., 1995; Swapnil et al., 2011; Elnazer et al., 2015; Abou ElAnwar et al., 2018; and Mekky et al., 2019).

\section{Degree of contamination (DC)}

The degree of contamination (DC) is defined as the computation of all contamination factors (Hakanson, 1980):

$$
D C=\sum_{1}^{n} C F
$$

The DC values are $\sim 19$ and 25 for Nile sediments and cultivated soils; respectively, Table 3 indicated that all the studied samples represented as a moderate degree of contamination (Caeiro et al., 2005).

Table 4 Enrichment factor of the sediments of the study samples

\begin{tabular}{|c|c|c|c|c|c|c|c|c|c|c|}
\hline Sample no & Location & Type & As & $\mathrm{Pb}$ & $\mathrm{Cr}$ & $\mathrm{Cd}$ & $\mathrm{Co}$ & $\mathrm{Zn}$ & $\mathrm{Cu}$ & $\mathrm{Ni}$ \\
\hline 1 & Luxor & Nile Sediments & 0.02 & 2.01 & 3.46 & 1.57 & 0.38 & 2.00 & 0.17 & 0.27 \\
\hline 2 & & & 0.02 & 1.57 & 2.75 & 1.20 & 0.40 & 1.79 & 0.15 & 0.23 \\
\hline 3 & & & 0.03 & 2.16 & 3.56 & 1.19 & 0.61 & 2.14 & 0.17 & 0.27 \\
\hline 4 & Aswan & & 0.00 & 0.55 & 0.07 & 0.64 & 0.27 & 0.29 & 0.06 & 0.08 \\
\hline 5 & & & 0.00 & 0.85 & 0.07 & 0.97 & 0.24 & 0.35 & 0.16 & 0.08 \\
\hline 6 & & & 0.04 & 0.22 & 0.11 & 1.08 & 0.27 & 0.40 & 0.07 & 0.10 \\
\hline 7 & Habo City & Agricultural soil & 0.17 & 0.16 & 0.74 & 0.61 & 0.52 & 0.58 & 0.15 & 0.46 \\
\hline 8 & & & 0.20 & 0.21 & 0.87 & 0.77 & 0.64 & 0.67 & 0.19 & 0.55 \\
\hline 9 & & & 0.19 & 0.20 & 0.67 & 0.73 & 0.58 & 0.58 & 0.15 & 0.49 \\
\hline 10 & Edfo & & 0.16 & 0.13 & 0.57 & 0.41 & 1.33 & 0.46 & 0.12 & 0.37 \\
\hline 11 & High Dam & & 0.00 & 0.25 & 1.29 & 0.52 & 1.09 & 3.19 & 0.23 & 0.16 \\
\hline 12 & & & 0.00 & 0.34 & 1.63 & 0.82 & 1.38 & 3.95 & 0.29 & 0.27 \\
\hline 13 & Fiyla & & 0.00 & 0.40 & 1.41 & 0.66 & 1.29 & 3.36 & 0.17 & 0.24 \\
\hline
\end{tabular}




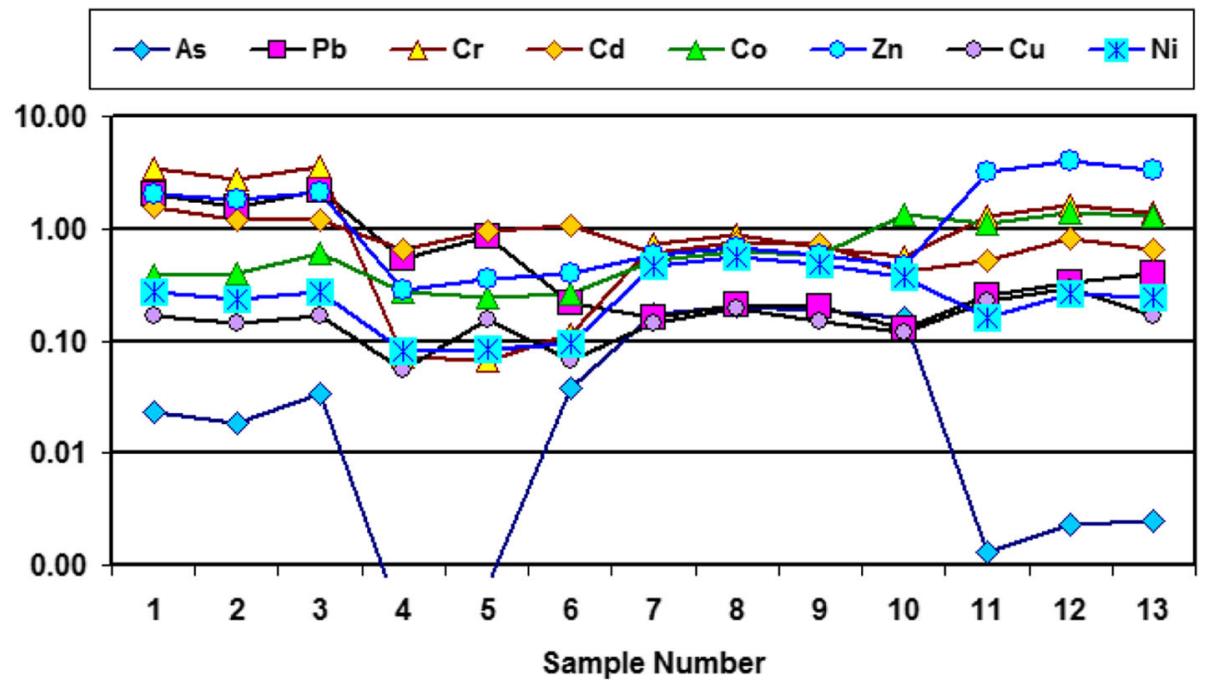

Fig. 5 Enrichment factor of the heavy metals of the studied samples

\section{Pollution load index (PLI)}

The pollution load index (PLI) proposed by Tomlinson et al., (1980), gives a simple and proportional means for assessing the level of heavy metal pollution. Thus, it is a distinctive index in the comparison of pollution rank in different localities (cf. Abou El-Anwar et al., 2018, and Mekky et al., 2019):

$$
P L I=\sqrt[n]{\mathrm{CF}_{1} \times C F_{2} \times C F_{3} \times \ldots \ldots \ldots \times \mathrm{CF}_{n}}
$$

where $n$ is the number of metals and CF is the contamination factors. PLI > 1 indicates pollution exists; PLI $<1$ indicates no metal pollution (Chakravarty and
Patgiri, 2009); and PLI = 1 indicates heavy metal loads close to the background level (Cabrera et al., 1999). The average value of PLI of the studied sediment samples (0.98) and soil cultivated is equal to 1.88 (Table 3 ). The values of PLI indicated the high load of heavy metals in the investigated cultivated soil than the Nile sediments samples. Consequently, it revealed the role of external discrete sources; vehicle exhaust and agricultural effect on soil pollution (cf. Elnazer, et al., 2015; Abou El-Anwar et al., 2018 and Mekky et al., 2019). Cd, Cr, Zn, and Ni possibly represented the main sources for the environmental pollution in Habo City and Edfo area.

Table 5 Ecological risk factor (Er) and pollution ecological risk index (PRI) of the study samples

\begin{tabular}{|c|c|c|c|c|c|c|c|c|c|}
\hline S. No. & & Type & $\mathrm{Pb}$ & $\mathrm{Cr}$ & $\mathrm{Cd}$ & Zn & $\mathrm{Cu}$ & $\mathrm{Ni}$ & PRI \\
\hline 1 & Luxor & Nile Sediments & 25.54 & 64.89 & 166.67 & 67.91 & 8.31 & 8.03 & 341.35 \\
\hline 2 & & & 25.99 & 67.2695 & 166.67 & 79.21 & 9.44 & 8.91 & 357.49 \\
\hline 3 & & & 29.01 & 70.2815 & 133.33 & 76.57 & 8.69 & 8.39 & 326.26 \\
\hline 4 & Aswan & & 27.40 & 43.8758 & 100.00 & 196.97 & 20.52 & 9.32 & 398.09 \\
\hline 5 & & & 38.76 & 46.8543 & 133.33 & 205.94 & 22.41 & 8.68 & 455.98 \\
\hline 6 & & & 11.36 & 50.2011 & 133.33 & 216.50 & 15.74 & 11.43 & 438.57 \\
\hline Average & & & 26.34 & 57.23 & 138.89 & 140.52 & 14.18 & 9.13 & 386.29 \\
\hline 7 & Habo City & Agricultural soil & 7.32 & 50.23 & 233.33 & 71.39 & 26.19 & 48.73 & 437.19 \\
\hline 8 & & & 8.60 & 53.5478 & 266.67 & 76.57 & 31.47 & 53.07 & 489.92 \\
\hline 9 & & & 9.49 & 48.5277 & 300.00 & 76.57 & 28.96 & 55.59 & 519.13 \\
\hline 10 & Edfo & & 6.10 & 40.6294 & 166.67 & 59.72 & 22.16 & 41.75 & 337.02 \\
\hline 11 & High Dam & & 2.68 & 5.22091 & 266.67 & 38.13 & 10.95 & 8.74 & 332.38 \\
\hline 12 & & & 3.00 & 4.4177 & 366.67 & 42.51 & 27.70 & 12.02 & 456.31 \\
\hline 13 & Fiyla & & 4.44 & 8.60112 & 466.67 & 55.60 & 13.47 & 33.37 & 582.15 \\
\hline Average & & & 5.95 & 30.17 & 295.24 & 60.07 & 22.99 & 36.18 & 450.59 \\
\hline
\end{tabular}




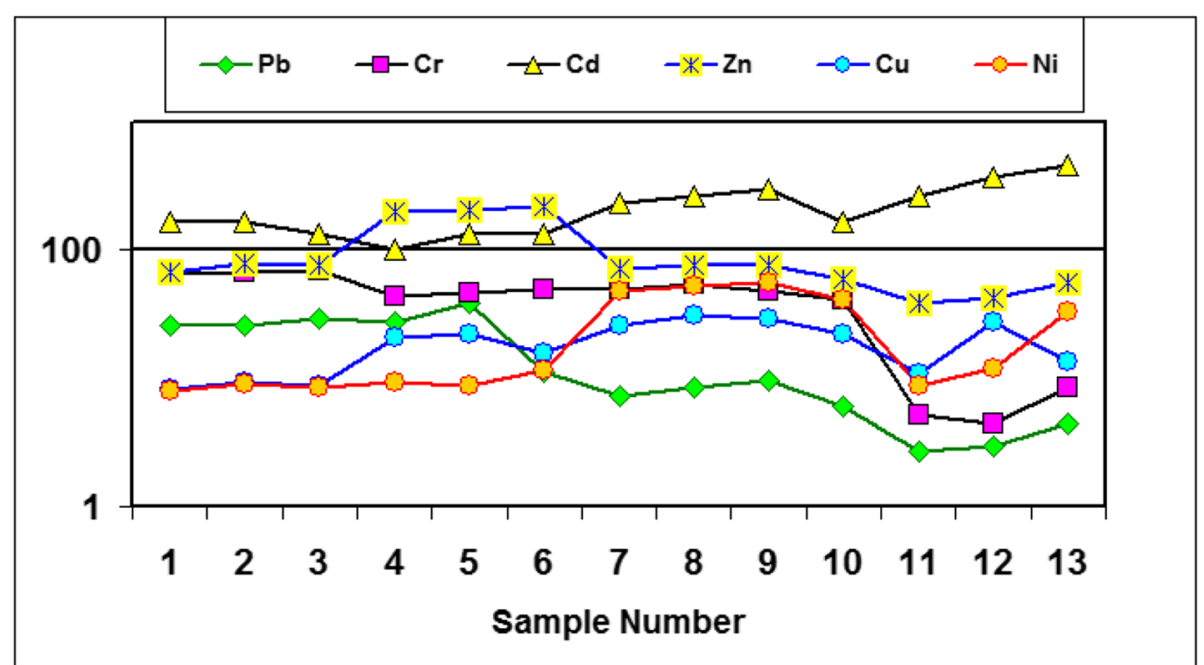

Fig. 6 ecological risk factor (Er) and pollution ecological risk index (PRI) of the study samples

\section{Pollution ecological risk index (PRI)}

PRI of the heavy metals is quantitatively evaluated by the ecological risk factor (Er) (Hakanson, 1980; Zhu et al., 2008). The PRI values were compared with grade of Er metal pollution risk on the environment classified by Hakanson (1980) and Shi et al., (2010).

$$
P R I=\sum_{1}^{n} \mathrm{Er}
$$

PRI $<150$ represented as low contamination; $150 \leq$ PRI $<300$ moderate contamination; $300 \leq$ PRI $<600$ considerable contamination and PRI $\geq 600$ represented a high contamination (Hakanson, 1980).

PRI calculation results of samples in Table 5 showed that the studied soil and sediments represented considerable contamination ecological risk (Hakanson, 1980). The cultivated soils are highly ecological risk than it of the studied sediments (PRI = $\sim 451$ and 386, respectively). The ecological risk comes mainly from the soil pollution with $\mathrm{Cd}, \mathrm{Cr}$, $\mathrm{Zn}$, and Ni. These metals have danger effect on plants and human health, and much attention must be paid to the study area quality.

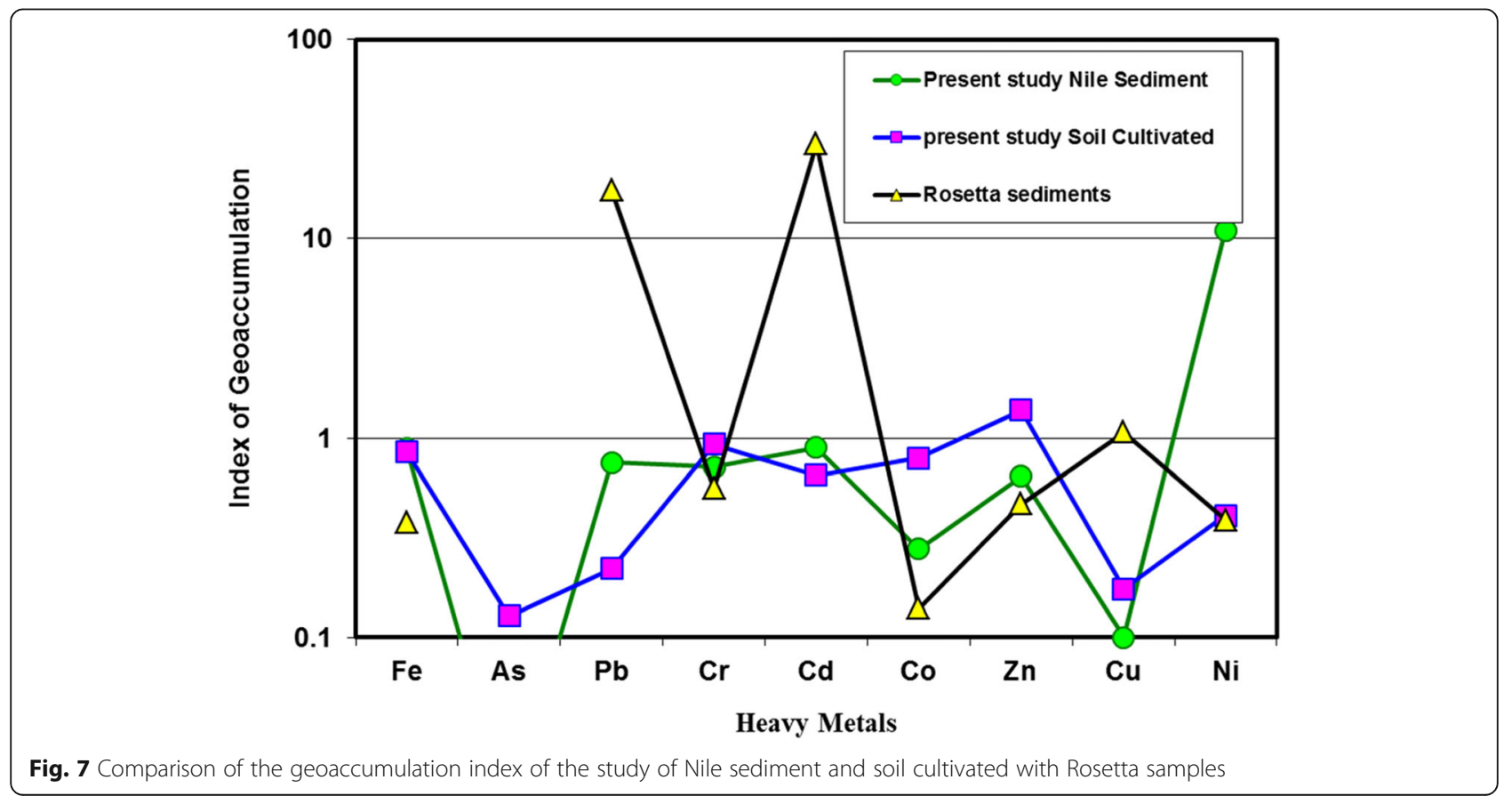




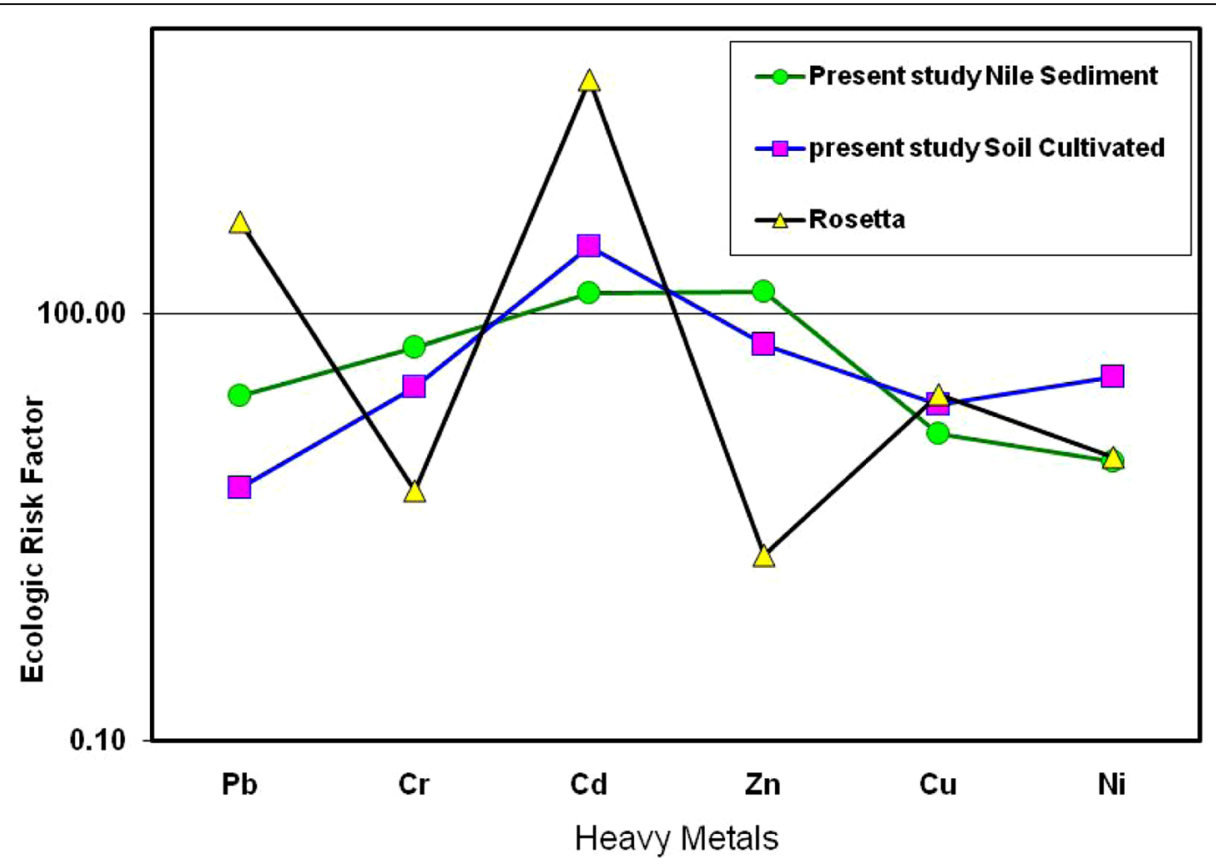

Fig. 8 Comparison of the contamination factor of the study of Nile sediment and soil cultivated with Rosetta samples.

\section{Comparison study samples with others in Lower and} Upper Egypt

The $I_{\text {geo }}$ value indicated that the Rosetta bottom sediments (Lower Egypt, studied with Abou El-Anwar, et al., 2018) are mainly (very strong) polluted with $\mathrm{Pb}$ and $\mathrm{Cd}$, and moderately polluted with $\mathrm{Cu}$ than the studied Nile sediments at Aswan and Luxor District (Fig. 7). Also, the calculated (CF) and (Er) revealed that the Rosetta bottom sediments are more polluted with $\mathrm{Pb}, \mathrm{Cd}$, and $\mathrm{Cu}$ (Figs. 8 and 9) than the studied samples.

While, comparing the studied cultivated soils with other localities along the Nile Valley; Sohag, El Minya,

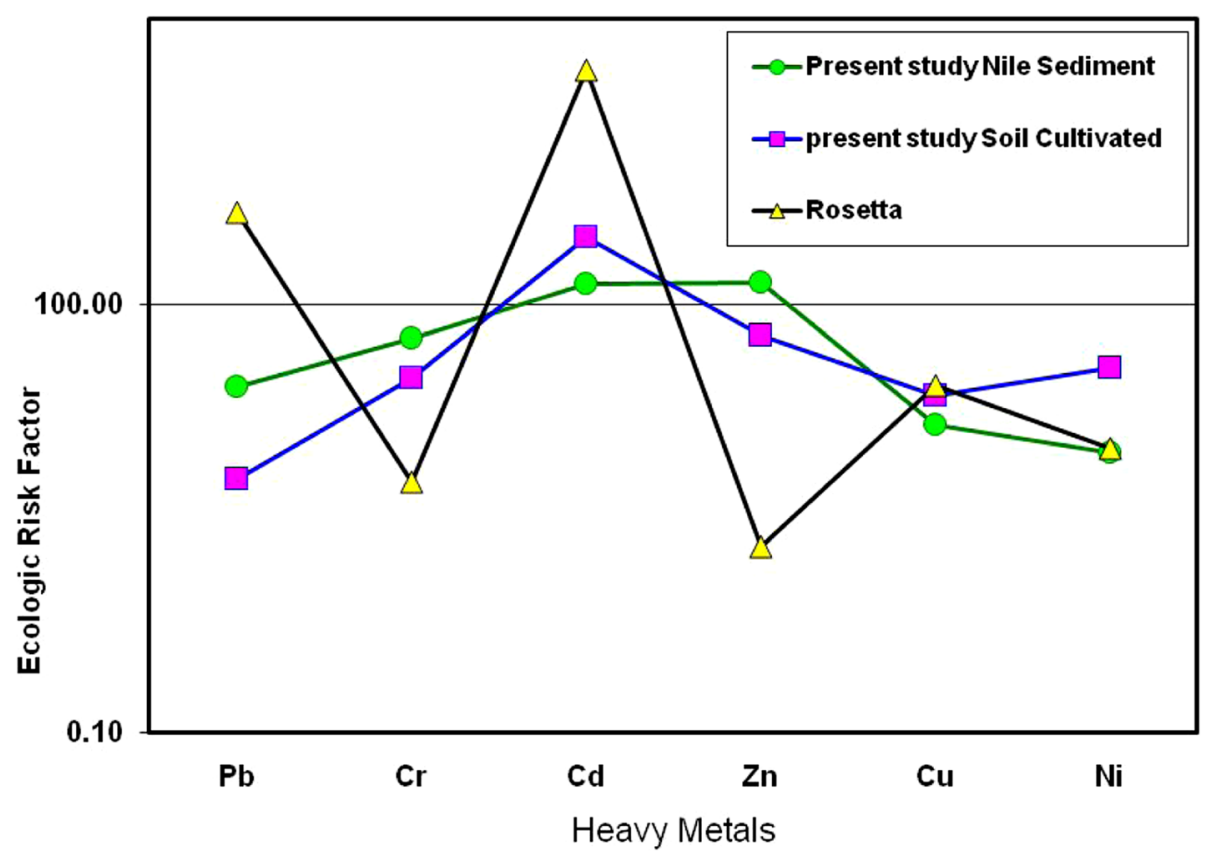

Fig. 9 Comparison of the ecologic risk factor of the study of Nile sediment and soil cultivated with Rosetta samples 


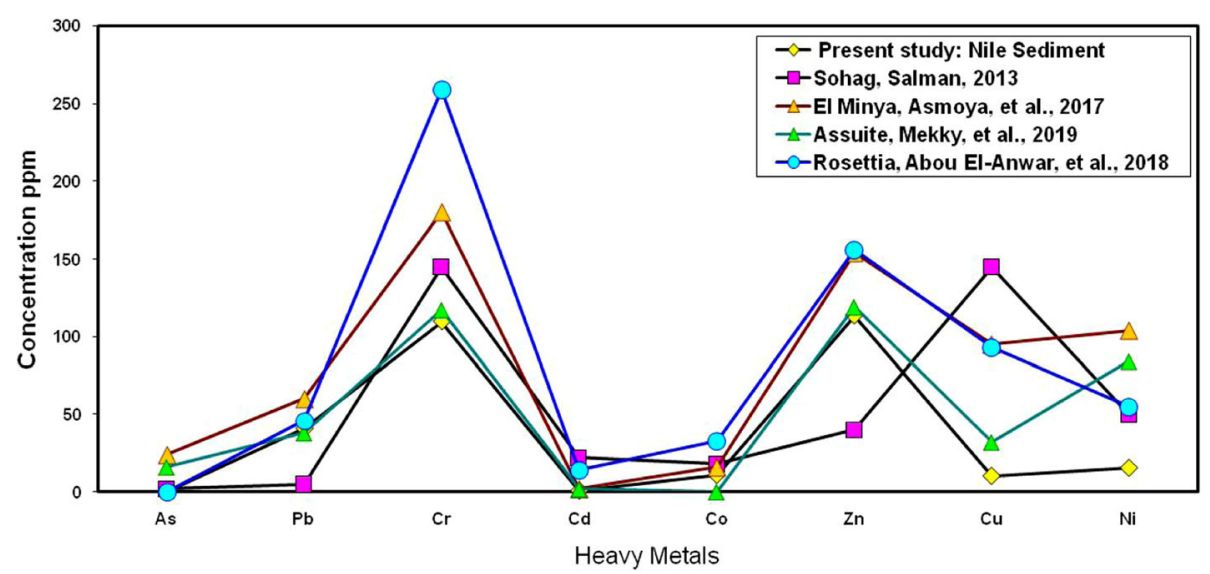

Fig. 10 Comparison the heavy metals study with other localities

and Assiut (Salman 2013, Asmoay 2017 and Mekky, et al., 2019, respectively), Governorates as well as the Rosetta soils (as Lower Egypt, Abou El-Anwar, et al., 2018) indicated that generally, the studied soil decreases in pollution than the lower Egypt and other local adjacent localities (Fig. 10). But, the concentration of $\mathrm{Zn}$ and Co is higher than Sohag and Assuit Governorates, respectively.

\section{Conclusions}

The calculated pollution indices indicated moderately load of heavy metals in the studied area. In addition, the studied cultivated soil has very high ecological risk with $\mathrm{Cd}$. PLI values revealed high load of heavy metals in the investigated cultivated soil samples than the Nile sediments.

$\mathrm{Cd}, \mathrm{Cr}, \mathrm{Zn}$, and $\mathrm{Ni}$ possibly represented the main sources for the environmental pollution, especially in Habo City and Edfo area. Thus, it is recommended to advice the farmers to decrease to the use of illegal harmful chemical, organic fertilizers and pesticides. Consequently, these anthropogenic elements are resulting from the industrial activities and irrigation drainage water.

Generally, all the concentration of the heavy metals is the studied sediments which are lower than those of the Nile Rosetta sediments (Abou El-Anwar, et al., 2018). Thus, the effect of pollution on cultivated soils and sediments increases from south to north trend of Egypt.

\section{Publisher's note}

Springer Nature remains neutral with regard to jurisdictional claims in published maps and institutional affiliations.

\section{Acknowledgements}

The author would like to thank the Geological Sciences Dept., National Research

Centre for facilitates during this work.

\section{Author's contributions}

Single author. The author read appoved the final manuscript.
Funding

No funding

Availability of data and materials

All data generated or analysed during this study are included in this published article

Ethics approval and consent to participate

Not applicable

Consent for publication

Not applicable

\section{Competing interests}

The author declares that he have no competing interests.

Received: 29 April 2019 Accepted: 19 November 2019

Published online: 09 December 2019

\section{References}

Abdu N, Abdullah AA, Abdulkadir A (2017) Heavy metals and soil microbes. Environ Chem Lett 15(1):65-84

Abou El-Anwar EA, Samy YM, Salman SA (2018) Heavy metals hazard in Rosetta Branch sediments, Egypt, J. Mater. Environ. Sci. 9, Issue; 7: 2142-2152

Ali H, Khan E (2019) Trophic transfer, bioaccumulation, and biomagnification of non-essential hazardous heavy metals and metalloids in food chains/ webs-Concepts and implications for wildlife and human health. Hum Ecol Risk Assess 25(6):1353-1376

Ali H, Khan E, llahi I, (2019) Environmental chemistry and ecotoxicology of hazardous heavy metals: environmental persistence, toxicity, and bioaccumulation," Journal of Chemistry, vol. 2019, Article ID 6730305, 14 pages. https://doi.org/https://doi.org/10.1155/2019/6730305

Asmoay ASA (2017) Hydrogeochemical studies on the water resources and soil characteristics in the Western Bank of the River Nile between Abu Qurqas and Dayr Mawas, El Minya Governorate, Egypt. Ph.D. thesis. Fac. Sci. Al-Azhar Univ, Egypt, p 255

Bakshi S, Banik C, He Z (2018) The impact of heavy metal contamination on soil health. In Reicosky (Edr): Managing soil health for sustainable agriculture Volume 2: Monitoring and management. Burleigh Dodds Series in Agricultural Science

Cabrera F, Clemente L, Barrientos DE (1999) Heavy metal pollution of soils affected by the Guadiamar toxic flood. Sci Total Environ 242(1-3):117-129

Caeiro S, Costa M, Ramos TB (2005) Assessing heavy metal contamination in Sado estuary sediment: an index analysis approach. Ecol Indicator 5:151-169

Chakravarty M, Patgiri AD (2009) Metal pollution assessment in sediments of the Dikrong river, N.E. India. J Hum Ecol 27(1):63-67

Chon HT, Kim KW, Kim JY (1995) Metal contamination of soils and dusts in Seoul metropolitan city, Korea. Environ Geochem Health 17:139-146 
Elnazer AA, Salman SA, Seleem EM, Abu El Ella EM (2015) Assessment of some heavy metals pollution and bioavailability in roadside soil of AlexandriaMarsa Matruh highway, Egypt. Int. J. Ecol. Article ID 689420, 7 p, doi: https:// doi.org/10.1155/2015/689420

Franco-Uria A, Lopez-Mateo C, Roca E, Fernandez-Marcos M (2009) Sources identification of heavy metals in pasture land by multivariate analysis in NW Spain, J. Hazard Mater 165(1-3):1008-1015

Gao XL, Chen CTA (2012) Heavy metal pollution status in surface sediments of the coastal Bohai Bay. Water Res 46:1901-1911

Goher ME, Farhat HI, Abdo MH, Salem GS (2014) Metal pollution assessment in the surface sediment of Lake Nasser, Egypt. Egypt J Aquat Res 40:213-224

Hafizur RS, Khanam D, MehediAdyel T, Shahidul Islam M., Aminul Ahsan M, AhedulAkbor (2012) Assessment of heavy metal contamination of agricultural soil around Dhaka Export Processing Zone (DEPZ), Bangladesh: implication of seasonal variation and indices. Appl Sci 2: 584-601.

Hakanson L (1980) An ecological risk index for aquatic pollution control: a sedimentological approach. Water Res 14:975-1001

Jovanović VS, Mitić V, Mandić SN, Ilić M, Simonović S (2015) Heavy metals in the postcatastrophic soils. In: Sherameti I, Varma A (eds) Heavy Metal Contamination of Soils: Monitoring and Remediation. Springer International Publishing, New York, pp 3-21

Kabata-Pendias A, Mukherjee AB (2007) Trace elements from soil to human. Springer Berlin Heidelberg New York: 550

Liaghati, T, Preda, M, Cox, M, 2003, Heavy metal distribution and controlling factors within coastal plain sediments, Bells Creek catchments, southeast Queensland, Australia, Environment International, 29: 935-948

Liu WH, Zhao JZ, Ouyang ZY (2005) Impacts of sewage irrigation on heavy metal distribution and contamination in Beijing, China. Environ Int 31:805-812

Loska K, Wiechula D (2003) Application of principal component analysis for the estimation of source heavy metal contamination in surface sediments from Rybnik reservoir. Chemosphere 51:723-733

Loska K, Wiechula D, Korus I (2004) Metal contamination of farming soils affected by industry. Environment Int 30:159-165

Mekky H.S, Abou El-Anwar EA, Salman SA, Elnazer AA, Abdel Wahab W, Asmoay AS (2019) Evaluation of heavy metals pollution by using pollution indices in the soil of Assiut District, Egypt. Egyptian Journal of Chemistry, DOI: https:// doi.org/10.21608/EJCHEM.2019.9720.1654

Mohankumar K, Hariharan V, Rao NP (2016) Heavy metal contamination in groundwater around industrial estate vs residential areas in Coimbatore, India. J Clin Diagn Res 10(4):5-7

Muller G (1979) Schwermetalle in den sedimenten des Rheins, VeranderungemSeit 1971. Umschau 79:778-783

Oliver MA, Gregory PJ (2015) Soil, food security and human health: a review. Euro J Soil Sci 66(2):257-276

Praveena SM, Ahmed A, Radojevic M, Abdullah MH, Aris AZ (2007) Factor-cluster analysis and enrichment study of mangrove sediments-an example from Mengkabong, Sabah. Malaysian J Anal Sci 11(2):421-430

Praveena SM, Ahmed A, Radojevic M, Abdullah MH, Aris AZ (2008) Heavy metals in mangrove surface sediment of Mengkabong lagoon, Sabah: Multivariate and geo-accumulation index approaches. Int J Environ Res 2(2):139-148

Qingjie G, Deng J, Xiang Y, Wang Q, Yang L (2008) Calculating pollution indices by heavy metals in ecological geochemistry assessment and a case study in parks of Beijing. J China Univ Geosci 19(3):230-241

Salman SA (2013) Geochemical and environmental studies on the territories west River Nile, Sohag Governorate Egypt. Ph.D. Thesis, Fac. Sci., Al-Azhar Uni., Egypt

Sarwar N, Imran M, Shaheen MR, Ishaque W, Kamran MA, Matloob A, Rehim A, Hussain S (2017) Phytoremediation strategies for soils contaminated with heavy metals: Modifications and future perspectives. Chemosphere 171:710-721

Sesha BR, Natesa U, Deepthi k (2010) Geochemical and statistical approach for evolution of heavy metal pollution in core sediments in southeast coast of India. Int J Environ Sci Tech 7 (2): 291-306

Shi G, Chen Z, Bi C, Li Y, Teng J, Wang L, Xu S (2010) Comprehensive assessment of toxic metals in urban and suburban street deposited sediments (SDSs) in the biggest metropolitan area of China Environ. Pollut 158:694-703

Simex SA, Helz GR (1980) Regional geochemistry of trace elements in Chesapeake Bay. Environ Geo 3:315-323

Swapnil R, Chopra AK, Pathak C, Sharma DK, Sharma R, Gupta PM (2011) Comparative study of some physicochemical parameters of soil irrigated with sewage water and canal water of Dehradun city, India. Arch Appl Sci Res 3(2):318-325
Tchounwou PB, Yedjou C, Patlolla G, Sutton DJ (2012) Heavy metals toxicity and the environment. EXS 101:133-164

Tomlinson DL, Wilson JG, Harris CR, Jeffney DW (1980) Problems in the assessment of heavy metal levels in estuaries and the formation of a pollution index. Helgoländer Meeresuntersuchungen 33(1-4):566-572

Yang J, Teng Y, Wu J, Chen H, Wang G, Song L, Yue W, Zuo R, Zhai Y (2017) Current status and associated human health risk of vanadium in soil in China. Chemosphere 171:635-643

Zhu W, Bian B, Li L (2008) Heavy metal contamination of road-deposited sediments in a medium size city of China. Environ Monit Assess 147(1-3): $171-181$

\section{Submit your manuscript to a SpringerOpen ${ }^{\circ}$ journal and benefit from:}

- Convenient online submission

- Rigorous peer review

- Open access: articles freely available online

- High visibility within the field

- Retaining the copyright to your article

Submit your next manuscript at $\boldsymbol{\nabla}$ springeropen.com 